\title{
KINERJA PERUSAHAAN
}

NAMA : I KETUT PURNAYASA

EMAIL : : ketutagus777@gmail.com

Entreprenure orientation terkait dengan berbagai cara untuk kinerja fungsi di perusahaan. Hubungan positif diamati antara inovasi dan kinerja R\&D dan antara proaktif dan kinerja pemasaran dan penjualan. Ada hubungan negatif antara pengambilan risiko dan kinerja produksi. Hasilnya juga menunjukkan hubungan positif berurutan dari R\&D melalui produksi dan pemasaran dan penjualan terhadap kinerja perusahaan secara keseluruhan. Oleh karena itu, disimpulkan bahwa fungsi R\&D, produksi dan pemasaran dan penjualan memperkuat satu sama lain dalam urutan yang logis dan saling melengkapi dalam pengaruhnya terhadap kinerja perusahaan secara keseluruhan.Open innovation adalah, "penggunaan aliran masuk dan keluar pengetahuan secara sengaja untuk mempercepat inovasi internal, dan memperluas pasar untuk penggunaan inovasi eksternal" (Chesbrough et al., 2006). Inti dari model inovasi terbuka adalah pengakuan bahwa saat ini, keunggulan kompetitif sering kali berasal dari koneksi masuk maupun keluar. Memanfaatkan koneksi masuk berarti memanfaatkan penemuan orang lain: perusahaan tidak perlu, dan memang tidak boleh, bergantung secara eksklusif pada R\&D mereka sendiri. Memanfaatkan inovasi terbuka keluar berarti bahwa, daripada mengandalkan sepenuhnya pada jalur internal ke pasar, perusahaan dapat mencari organisasi eksternal dengan model bisnis yang lebih cocok untuk mengkomersialkan teknologi tertentu (Chesbrough, 2002).

Risk governance atau pengelolaan risiko mengacu pada institusi, aturan konvensi, proses dan mekanisme dimana keputusan tentang risiko diambil dan diimplementasikan. Ini dapat bersifat normatif dan positif, karena menganalisis dan merumuskan strategi manajemen risiko untuk menghindari dan / atau mengurangi biaya manusia dan ekonomi yang disebabkan oleh bencana. Tata kelola risiko melampaui analisis risiko tradisional untuk memasukkan keterlibatan dan partisipasi berbagai pemangku kepentingan serta pertimbangan konteks hukum, politik, ekonomi dan sosial yang lebih luas di mana risiko dievaluasi dan dikelola. Ruang lingkup tata kelola risiko mencakup kesehatan dan keselamatan publik, lingkungan, teknologi lama dan baru, keamanan, keuangan, dan banyak lainnya. 
Membentuk sebuah jaringan komersial yang krusial bagi perusahaan yang menguntungkan untuk memungkinkan bagi mereka mendapatkan dan mengolah sumber daya yang berharga. Di suatu sisi, terdapat beberapa penelitian lain mengemukakan bahwa perusahaan dengan jaringan sosial yang lebih besar memungkinkan perusahaan mengalami kinerja yang buruk, terlebih lagi ketika terjadi eksploitasi hubungan

Penelitian ini menerapkan metode bersekala besar dengan unit analisa pada suatu usaha kecil atau menengah. Didapati survei secara acak yang dilakukan dengan daftar kuesioner melalui metode sampel acak. Informasi yang diperutukan menjawab pertanyaan survey kusioner yang mengacu pada hubungan antara variabel yang diamati, termasuk kinerja perusahaan, struktur jaringan sosial, kepercayaan, dan pengembangan produk.

https://www.emerald.com/insight/content/doi/10.1108/MRR-03-2017-0092/full/html

https://en.wikipedia.org/wiki/Risk_governance

https://journals.sagepub.com/doi/10.1111/j.1741-6248.2007.00082.x

https://timreview.ca/article/675\#: : text=Open\%20innovation\%20is\%20\%22the\%20use,et\%20al.\%2C\%2 02006).\&text=Moreover\%2C\%20this\%20article\%20examines\%20the,of\%20SMEs\%2C\%20and\%20firm\%2 Operformance. 